\title{
MADRASAH PROMOTION STRATEGIES IN THE GLOBAL WORK MARKET 4.0
}

\author{
Sukarman \\ Universitas Islam Nahdlatul Ulama (UNISNU) Jepara \\ pakar@unisnu.ac.id \\ Raharjo \\ Universitas Islam Negeri (UIN) Walisongo Semarang \\ raharjo@walisongo.ac.id \\ Fatah Syukur \\ Universitas Islam Negeri (UIN) Walisongo Semarang \\ fsyukur68@gmail.com
}

\begin{abstract}
Students are an important element in education. Successful educational institutions are those who are successful in student recruitment. Educational institutions that are successful in student recruitment are institutions that have succeeded in gaining trust from the community. Madrasah Aliyah Matholiul Huda Jepara as one of the Islamic-style educational institutions has its own challenges in recruiting students. This madrasa is a madrasa that successfully competes with schools and other madrassas in gaining trust from the community which is marked by the success of the student recruitment program. This research attempts to reveal the strategies adopted by Madrasah Aliyah Matholiul Huda Jepara in promoting their institutions. This research is a case study research that uses a qualitative descriptive approach. This study uses interviews, observation, and documentation in collecting data. data reduction, data display, data verification and triangulation are used for data validity analysis. The findings of this study are divided into two aspects namely the method and media of promotion used. First, Madrasah Aliyah Matholiul Huda applies direct and indirect promotion methods. Second, Madrasah Aliyah Matholiul Huda uses conventional and digital (online) promotional media. This paper provides an alternative solution for madrassas who have backgrounds or problems in the recruitment of students, especially promotion strategies. The conclusion of this paper is that to be successful in recruiting students, madrassas must choose the appropriate method and media in promoting madrassas by paying attention to the SWOT analysis.
\end{abstract}

Keywords : madrasa promotion, students recruitment 


\begin{abstract}
Abstrak
Peserta didik Merupakan salah satu elemen penting dalam pendidikan. Lembaga pendidikan yang berhasil adalah mereka yang sukses dalam rekrutmen peserta didik. Lembaga pendidikan yang sukses dalam rekrutmen peserta didik adalah lembaga yang berhasil memperoleh kepercayaan dari masyarakat. Madrasah Aliyah Matholiul Huda Jepara sebagai salah satu lembaga pendidikan bercorak Islami memiliki tantangan tersendiri dalam rekrutmen peserta didik. Madrasah ini merupakan madrasah yang sukses bersaing dengan sekolah dan madrasah lain dalam mendapatkan kepercayaan dari masyarakat yang ditandai dengan suksesnya program rekrutmen peserta didik. Penelitian ini berusaha mengungkapkan strategi yang diterapkan oleh Madrasah Aliyah Matholiul Huda Jepara dalam mempromosikan lembaganya. Penelitian ini merupakan penelitian studi kasus yang menggunakan pendekatan deskriptif kualitatif. Penelitian ini menggunakan wawancara, observasi, dan dokumentasi dalam mengumpulkan data. reduksi data, display data, verifikasi data dan Triangulasi digunakan untuk analisis keabsahan data. Temuan dari penelitian ini terbagi menjadi dua aspek yakni metode dan media promosi yang digunakan. Pertama, Madrasah Aliyah Matholiul Huda menerapkan metode promosi langsung dan tidak langsung. Kedua, Madrasah Aliyah Matholiul Huda menggunakan media promosi konvensional dan digital (online). Tulisan ini memberi alternatif solusi bagi madrasah yang memiliki latar belakang atau permasalahan dalam rekrutmen peserta didik khususnya strategi promosi. Simpulan dari tulisan ini adalah bahwa untuk sukses dalam rekrutmen peserta didik, madrasah harus memilih metode dan media yang sesuai dalam promosi madrasah dengan memperhatikan analisis SWOT.
\end{abstract}

Kata kunci: promosi madrasah, rekrutmen peserta didik

\title{
Pendahuluan
}

Madrasah adalah sekolah yang memiliki karakteristik khusus yaitu bercorak keagamaan (Islam). Glen Hardraker (1019) Madrasah didefinisikan sebagai sekolah Islam atau dar al-ulum-house of knowledge. ${ }^{1}$ Madrasah sebagai lembaga penyelenggara pendidikan tentu membutuhkan siswa. Eksistensi suatu Madrasah dapat diukur dari kestabilan atau peningkatan jumlah siswa yang diterima setiap tahunnya. Dengan kata lain Madrasah yang baik adalah madrasah yang memiliki jumlah siswa yang stabil atau bahkan meningkat dari tahun ke

\footnotetext{
1 Glen Hardaker and Aishah Ahmad Sabki, Pedagogy in Islamic Education: The Madrasah Context, 1st ed. (United Kingdom: Emerald Group Publishing, 2019).
} 
tahun dapat disebut sebagai madrasah yang sukses dalam rekritmen siswa. Sebaliknya sekolah yang mengalami penurunan jumlah siswa dari tahun ke tahun dapat dikatakan sebagai madrasah yang gagal dalam dalam rekruitmen siswa.

Jepara sebagai kota dengan penduduk mayoritas muslim memiliki banyak sekali madrasah mulai dari Madrasah Ibtidaiyah, Madrasah Tsanawiyah, dab Madrasah Aliyah yang tersebar di sebanyak 16 kecamatan. Berikut data statistik madrasah di Kabupaten Jepara berdasarkan data Kementerian Agama Kabupaten Jepara tahun 2018. ${ }^{2}$

Table 1. The number of madrasah and students in Jepara Regencies 2018

\begin{tabular}{lccccc}
\hline \multicolumn{1}{c}{ Level } & & $\begin{array}{c}\text { Total of } \\
\text { state } \\
\text { madrasah }\end{array}$ & $\begin{array}{c}\text { Total of } \\
\text { students }\end{array}$ & $\begin{array}{c}\text { Total of } \\
\text { private } \\
\text { madrasah }\end{array}$ & $\begin{array}{c}\text { Total of } \\
\text { students }\end{array}$ \\
\hline $\begin{array}{l}\text { Madrasah } \\
\begin{array}{l}\text { School) } \\
\text { Madrasah Tstidaiyah (Primary }\end{array}\end{array}$ & 2 & 1.345 & 190 & 34.323 \\
$\begin{array}{l}\text { High School) } \\
\text { Madrasah Aliyah }\end{array}$ & (Secondary & 2 & 1.882 & 111 & 24.373 \\
High School) & (First & 2 & 1.447 & 62 & 12.437 \\
\hline
\end{tabular}

Dari sekian Madrasah yang ada di Jepara Madrasah Aliyah Matholiul Huda sebagai salah satu Madrasah swasta terbesar di Jepara yang memiliki kualitas yang baik dalam rekruitmen siswa. Madrasah Aliyah Matholiul Huda merupakan salah satu dari sekian Madrasah Aliyah di Jepara yang mampu mempertahankan eksistensinya dengan menjaga stabilitas rekrutmen siswa melalui strategi promosi. Promosi madrasah ini dilakukan dalam rangka memasarkan madrasah kepada publik dengan harapan memperoleh perhatian dari masyarakat yang bermuara pada peningkatan rekrutmen siswa.

Untuk melakukan promosi setiap lembaga penyelenggara pendidikan menggunakan strategi yang meliputi teknik dan media. Teknik dan media yang digunakan untuk mempromosikan lembaganya beragam. Ada yang menggunakan media yang konvensional misalnya media cetak seperti pamflet atau brosur hingga media yang paling mutakhir seperti internet, media sosial misalnya website

2 Religion Ministry of Jepara Regency, “Open Data Kabupaten Jepara," 2018, http://opendata.jepara.go.id/id/group/pendidikan website: http://opendata.jepara.go.id/id/dataset/jumlah-madrasah-ibtidaiyah-swasta-kabupaten-jeparatahun-2018. 
sekolah, facebook, twitter, youtube, instagram, dan media lainnya ${ }^{3}$.

Di era digital 4.0 banyak lembaga pendidikan yang menggunakan strategi promosi melalui media online seperti internet dan media sosial. Meskipun hal ini memberi dampak bagi rekritmen siswa namun ada juga sebaliknya. Artinya, strategi promosi melalui internet dan media sosial bagi sebagian lembaga membawa dampak signifikan pada rekrutmen siswa. Dengan kata lain penggunaan internet dan media sosial sebagai media promosi tidak menjamin

\footnotetext{
${ }^{3}$ Nicole M Lee and Patrick F Merle, "Media Relations and Universities : An Assessment of Digital Newsrooms," Journal of Marketing for Higher Education 28, no. 2 (2018): 1-15, doi:10.1080/08841241.2018.1467991; Bart Kittle et al., "Journal of Marketing for Higher Education Using College Web Sites for Student Recruitment: A Relationship Marketing Study Using College Web Sites for Student Recruitment : A Relationship Marketing Study," no. October 2014 (2008): 37-41, doi:10.1300/J050v11n03; Muhammad Zaffwan Idris and T W Allan Whitfield, "Swayed by the Logo and Name: Does University Branding Work?," Journal of Marketing for Higher Education 24, no. 1 (2015): 37-41, doi:10.1080/08841241.2014.919979; Adam Peruta and Alison B Shields, "Marketing Your University on Social Media: A Content Analysis of Facebook Post Types and Formats," Journal of Marketing for Higher Education 28, no. 2 (2018): 1-17, doi:10.1080/08841241.2018.1442896; Esperanza Garza Salgado and Marcelo Royo Vela, "Brand Fan Pages Experience and Strength as Antecedents to Engagement and Intensity of Use to Achieve HEIS 'Brand Loyalty," Journal of Marketing for Higher Education 29, no. 1 (2019): 102-20, doi:10.1080/08841241.2019.1605437; Richard Scullion and Mike Molesworth, "Normalisation of and Resistance to Consumer Behaviour in Higher Education" 1241, no. November (2016), doi:10.1080/08841241.2016.1248104; Melissa Clark, Monica B Fine, and Cara-lynn Scheuer, "Relationship Quality in Higher Education Marketing: The Role of Social Media Engagement," Journal of Marketing for Higher Education 27, no. 1 (2017): 40-58, doi:10.1080/08841241.2016.1269036; André Pusey, "Strike , Occupy , Transform! Students , Subjectivity and Struggle" 1241, no. November (2016), doi:10.1080/08841241.2016.1240133; Lili Gai, Chunhao Xu, and Lou E Pelton, "A Netnographic Analysis of Prospective International Students 'Decision-Making Process: Implications for Institutional Branding of American Universities in the Emerging Markets," Journal of Marketing for Higher Education 26, no. 2 (2016): 1-18, doi:10.1080/08841241.2016.1245233; Raj Agnihotri et al., "Developing a Stakeholder Approach for Recruiting Top-Level Sales Students," 2014, doi:10.1177/0273475314522039; Muhammad Tahir Jan and Djihane Ammari, "Advertising Online by Educational Institutions and Students â€TM Reaction: A Study of Malaysian Universities Advertising Online by Educational Institutions and Students 'Reaction: A Study of Malaysian Universities," Journal of Marketing for Higher Education 26, no. 2 (2016): 1-13, doi:10.1080/08841241.2016.1245232; Marcelo Royo-vela and Ute Hünermund, "Effects of Inbound Marketing Communications on HEIs ' Brand Equity: The Mediating Role of the Student ' S Decision-Making Process . An Exploratory Research," Journal of Marketing for Higher Education 26, no. 2 (2016): 1-25, doi:10.1080/08841241.2016.1233165; Richard Rutter, Fiona Lettice, and John Nadeau, "Brand Personality in Higher Education: Anthropomorphized University Marketing Communications" 1241, no. August (2016), doi:10.1080/08841241.2016.1213346; Jenna Marie Condie et al., "Personalizing Twitter Communication : An Evaluation of ' Rotation-Curation' for Enhancing Social Media Engagement within Higher Education," Journal of Marketing for Higher Education 28, no. 2 (2018): 1-18, doi:10.1080/08841241.2018.1453910; Nadine M Robinson and Kevin G Celuch, "Strategic and Bonding Effects of Enhancing the Student Feedback Process" 26, no. 1 (2016): 20-40, doi:10.1080/08841241.2016.1146386; Kristiina Herold, Anssi Tarkiainen, and Sanna Sundqvist, "How the Source of Word-of-Mouth Influences Information Processing in the Formation of Brand Attitudes" 1241 (2016), doi:10.1080/08841241.2016.1146387.
} 
keberhasilan dalam rekrutmen siswa. Penelitian ${ }^{4}$ yang dilakukan pada 66 sekolah di Amerika Serikat menyatakan bahwa penggunaan media sosial utamanya facebook tidak berdampak pada peningkatan keterlibatan public dalam promosi yang dilakukan oleh sekolah. Pertanyaan utamanya adalah, ketika promosi melalui internet dan media sosial tidak menjamin tercapainya tujuan promosi, lalu strategi apa yang ditempuh oleh Madrasah Aliyah Matholiul Huda Jepara dalam mempromosikan madrasahnya ?

\section{Metode}

Tulisan ini merupakan kajian penelitian studi kasus ${ }^{5}$ di Madrasah Aliyah Matholiul Huda Jepara. Penelitian ini merupakan penelitian deskriptif dengan menggunakan pendekatan kualitatif yang memaparkan data fakta di lapangan ${ }^{6}$. Teknik pengumpulan yang digunakan dalam penelitian meliputi wawancara, observasi dan dokumentasi ${ }^{7}$. Wawancara mendalam dilakukan melalui beberapa teknik antar lain melalui telepon, surat, mailing questioner ${ }^{8}$. Keabsahan data penelitian ini dilakukan dengan triangulasi baik triangulasi teknik dan triangulasi sumber ${ }^{9}$. hal ini dimaksudkan agar data yang diperoleh benar-benar valid.

\footnotetext{
${ }^{4}$ Peruta and Shields, "Marketing Your University on Social Media: A Content Analysis of Facebook Post Types and Formats."

5 Mehraneh Davari, Payam Noursalehi, and Abbas Keramati, "Data Mining Approach to Professional Education Market Segmentation: A Case Study," Journal of Marketing for Higher Education 29, no. 1 (2018): 1-22, doi:10.1080/08841241.2018.1545724; Reginald T Dillingham Ii et al., "A Latent-Class Discrete-Choice Model of Demand for Economics Electives : A Case Study on the Challenge to Increase Enrollment" 1241 (2018), doi:10.1080/08841241.2018.1426673; Lamri Laouamer and Omar Tayan, "An Enhanced SVD Technique for Authentication and Protection of Text-Images Using a Case Study on Digital Quran Content with Sensitivity Constraints," Life Science Journal 10, no. 2 (2013): 2591-97.

${ }^{6}$ W Lawrence Neuman, Social Research Methods: Qualitative and Quantitative Approaches, 7th ed. (United States of America: Pearson Education Limited, 2014); Prabhat Pandey and Meenu Mishra Pandey, RESEARCH METHODOLOGY: TOOLS AND TECHNIQUES (Romania, European Union: BRIDGE CENTER, 2015); Nicholas Walliman, RESEARCH METHODS THE BASICS (USA and Canada: Routledge, 2011); Directorate of Distance Education, Research Methodology (New Delhi: EXCEL BOOKS PRIVATE LIMITED, 2012); C. R. Kothari, Research Methodology: Methods \& Techniques (New Delhi, India: New Age International (P) Limited, Publisher, 2004); "Research Methods," n.d.; Ranjit Kumar, RESEARCH METHODOLOGY, 3rd ed. (Los Angeles, London, New Delhi, Singapore, Washington DC: SAGE Publications Ltd, 2011); Research Methods in Psychology PSYCHOLOGICAL RESEARCH - OBJECTIVES AND GOALS , PROBLEMS , HYPOTHESIS AND, n.d.

7 Walliman, RESEARCH METHODS THE BASICS; Education, Research Methodology; "No Title," 1992.

${ }^{8}$ Pandey and Pandey, RESEARCH METHODOLOGY: TOOLS AND TECHNIQUES.

9 Walliman, RESEARCH METHODS THE BASICS; Neuman, Social Research Methods: Qualitative and Quantitative Approaches.
} 


\section{Hasil}

Madrasah Aliyah Matholiul Huda Jepara melakukan kegiatan promosi dalam rangka memasarkan madrasahnya dengan tujuan meningkatkan keterlibatan publik. Tujuan utamanya adalah menarik simpati publik. ${ }^{10}$ Ketika simpati public meningkat maka kepercayaan publik terhadap Madrasah Aliyah Matholiul Huda Jepara akan meningkat. Ketika kepercayaan public meningkat maka meningkat pula rekrutmen siswa. Strategi promosi yang dilakukan oleh Madrasah Aliyah Matholiul Huda Jepara dalam rangka merekrut siswa meliputi dua komponen utama yakni Metode dan media promosi. Baik promosi yang langsung yaitu metode yang terjadi secara interaktif dalam pemasaran produk atau jasa. Metode ini melibatkan adanya komunikasi antara dua pihak yakni penyedia produk baik barang maupun layanan atau jasa ${ }^{11}$. Promosi penting dilakukan bentuk komunikasi kepada pengguna (publik). Promosi merupakan element gabungan sebagai elemen penting 4 P's yang terdiri atas Product, price, place dan promotion dalam marketing mix ${ }^{12}$.

\section{Strategi promosi Madrasah Aliyah Matholiul Huda Jepara}

Di era teknologi informasi 4.0 yang ditandai dengan pergeseran dari data manual kepada data digital berdampak pada dunia pendidikan ${ }^{13}$. Demikian juga dengan Madrasah Aliyah Matholiul Huda Jepara. Promosi madrasah yang dilakukan oleh Madrasah Aliyah Matholiul Huda Jepara dalam memasarkan madrasahnya dengan melakukan berbagai strategi sebagai berikut;

a. website madrasah

Website hampir menjadi media wajib yang harus dimiliki oleh semua lembaga baik lembaga yang bergerak dalam industri dan perdagangan lembaga penyelenggara pendidikan di era 4.0. ${ }^{14}$. Madrasah Aliyah Matholiul Huda

\footnotetext{
${ }^{10}$ Muhaimin, Sutiah, and Sugeng Listyo Prabowo, Manajemen Pendidikan: Aplikasinya Dan Penyusunan Rencana Pengembangan Sekolah Dan Madrasah, 5th ed. (Jakarta: Prenada Media Gorup, 2015).

${ }^{11}$ Kruti Shah, Advertising And Promotion An IMC Perspective (New Delhi: Tata McGraw-Hill Education, 2009).

12 Michael J. Baker, RESEARCH FOR MARKETING, 1st ed. (London: MACMILLAN EDUCATION LTD, 1991).

13 Peruta and Shields, "Marketing Your University on Social Media: A Content Analysis of Facebook Post Types and Formats."

14 Ibid.; Lee and Merle, "Media Relations and Universities: An Assessment of Digital Newsrooms"; Salgado and Vela, "Brand Fan Pages Experience and Strength as Antecedents to Engagement and Intensity of Use to Achieve HEIS ' Brand Loyalty"; Clark, Fine, and Scheuer,
} 
Jepara sebagai lembaga penyelenggara pendidikan memanfaatkan website untuk meningkatkan keterlibatan public. Website dijadikan sebagai media untuk mempromosikan madrasah. Melalui website Madrasah mempromosikan dengan menampilkan informasi penting terkait madrasah. Konten website madrasah ini menampilkan berbagai menu antara lain profil madrasah, akademik, UBK, download. Selain itu website madrasah ini juga menampilkan alamat jelas dan nomor telepon madrasah.

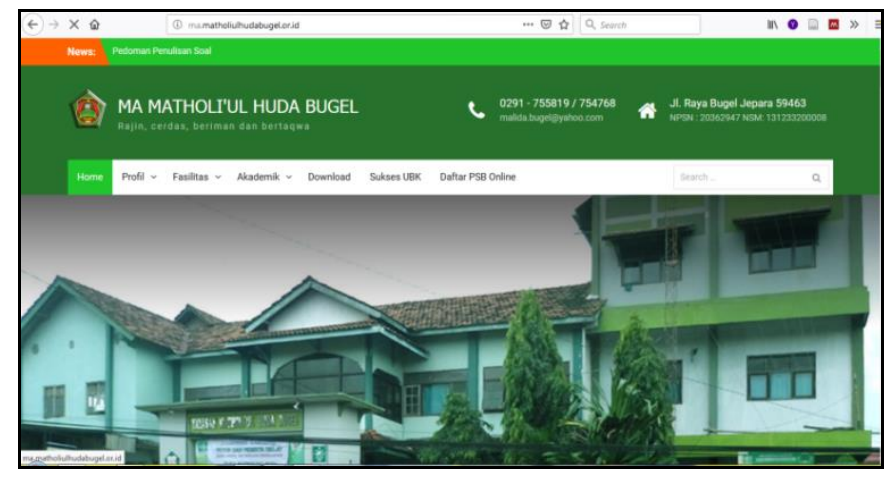

\section{Figure 1. website of Madrasah Aliyah Matholiul Huda Jepara}

\section{b. Facebook madrasah}

Facebook sebagai salah satu media promosi yang digunakan oleh lembaga penyelenggara pendidikan. Demikian pula dengan madrasah. Dalam melakukan promosi, terlepas berdampak signifikan terhadap keterlibatan public rekrutmen murid atau tidak. Pada dasarnya facebook bukan penentu berhasil atau tidaknuya promosi madrasah namun konten postingan di facebook juga ikut menentukan keberhasilan atau gagalnya promosi madrasah ${ }^{15}$.

\footnotetext{
"Relationship Quality in Higher Education Marketing: The Role of Social Media Engagement"; Julie Robson et al., "Working up a Debt : Students as Vulnerable Consumers Working up a Debt : Students as Vulnerable Consumers," Journal of Marketing for Higher Education 0, no. 0 (2017): 1-16, doi:10.1080/08841241.2017.1391922; Agnihotri et al., "Developing a Stakeholder Approach for Recruiting Top-Level Sales Students"; Jan and Ammari, "Advertising Online by Educational Institutions and Students â€TM Reaction: A Study of Malaysian Universities Advertising Online by Educational Institutions and Students 'Reaction: A Study of Malaysian Universities"; Royo-vela and Hünermund, "Effects of Inbound Marketing Communications on HEIs ' Brand Equity: The Mediating Role of the Student' S Decision-Making Process . An Exploratory Research"; Condie et al., "Personalizing Twitter Communication : An Evaluation of " Rotation-Curation ' for Enhancing Social Media Engagement within Higher Education"; Mark R Young and Mark R Young, "Journal of," no. May 2009 (2010), doi:10.1177/0273475309335353; Robinson and Celuch, "Strategic and Bonding Effects of Enhancing the Student Feedback Process."

${ }^{15}$ Lee and Merle, "Media Relations and Universities : An Assessment of Digital Newsrooms"; Peruta and Shields, "Marketing Your University on Social Media: A Content Analysis of
} 
Madrasah Aliyah Matholiul Huda Jepara memanfaatkan media sosial facebook untuk membuat jejaring yang melibatkan semua kalangan yang terkait dengan melibatkan baik guru, pelajar, alumni dan masyarakat umum. Media ini digunakan dengan alasan bahwa hampir setiap orang dengan mudah mengakses facebook. Segala macam informasi dapat dengan mudah disebarkan dan diakses melalui facebook.

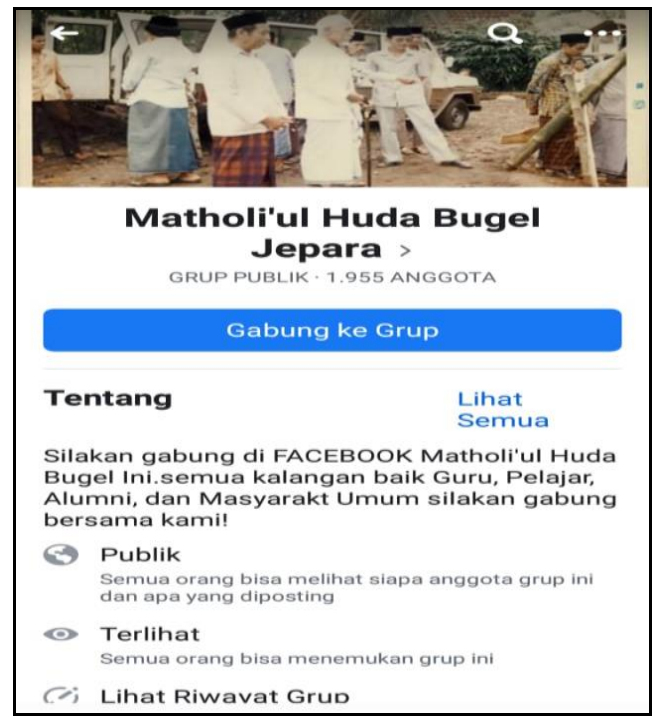

Figure 2. facebook of Madrasah Aliyah Matholiul Huda Jepara

c. Instagram

Instagram sebagai salah satu media sosial yang banyak digunakan oleh publik dimanfaatkan pula oleh banyak lembaga pendidikan. ${ }^{16}$. Madrasah Aliyah Matholiul Huda juga memanfatkan instagram sebagai media

Facebook Post Types and Formats"; Salgado and Vela, "Brand Fan Pages Experience and Strength as Antecedents to Engagement and Intensity of Use to Achieve HEIS ' Brand Loyalty"; Clark, Fine, and Scheuer, "Relationship Quality in Higher Education Marketing: The Role of Social Media Engagement"; Condie et al., "Personalizing Twitter Communication: An Evaluation of " Rotation-Curation ' for Enhancing Social Media Engagement within Higher Education."

${ }^{16}$ Lee and Merle, "Media Relations and Universities : An Assessment of Digital Newsrooms"; Peruta and Shields, "Marketing Your University on Social Media: A Content Analysis of Facebook Post Types and Formats"; Salgado and Vela, "Brand Fan Pages Experience and Strength as Antecedents to Engagement and Intensity of Use to Achieve HEIS ' Brand Loyalty"; Clark, Fine, and Scheuer, "Relationship Quality in Higher Education Marketing: The Role of Social Media Engagement"; Agnihotri et al., "Developing a Stakeholder Approach for Recruiting TopLevel Sales Students"; Jan and Ammari, "Advertising Online by Educational Institutions and Students â€TM Reaction: A Study of Malaysian Universities Advertising Online by Educational Institutions and Students ' Reaction: A Study of Malaysian Universities"; Royo-vela and Hünermund, "Effects of Inbound Marketing Communications on HEIs ' Brand Equity: The Mediating Role of the Student 'S Decision-Making Process . An Exploratory Research"; Robinson and Celuch, "Strategic and Bonding Effects of Enhancing the Student Feedback Process"; Condie et al., "Personalizing Twitter Communication: An Evaluation of " RotationCuration ' for Enhancing Social Media Engagement within Higher Education.” 
promosinya. Promosi via instagram dialkukan dengan cara menampilkan events atau peristiwa yang berkenaan dengan kesiswaan dan kegiatan madrasah.

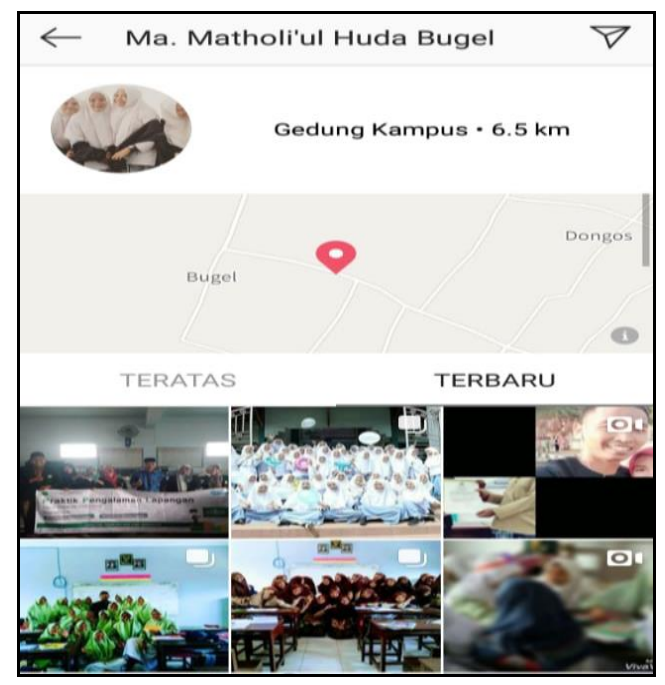

Figure 3. instagram of Madrasah Aliyah Matholiul Huda Jepara

d. Twitter

Twitter sebagai media yang banyak digunakan oleh public dimanfaatkan oleh Madrasah Aliyah Matholiul Huda sebagai media promosi. Twitter digunakan untuk menjaring keterlibatan masyarakat. di Negara-negara maju twitter menjadi salah satu alternative media yang digunakan untuk media promosi sekolah ${ }^{17}$.

e. Youtube

Youtube salah satu media sosial yang banyak dikunjungi oleh masyarakat banyak dimanfaatkan oleh lembaga pendidikan untuk mempromosikan lembaganya. ${ }^{18}$, pinterest pages ${ }^{19}$. Video sebagai konten utama dari Youtube

${ }^{17}$ Lee and Merle, "Media Relations and Universities : An Assessment of Digital Newsrooms"; Salgado and Vela, "Brand Fan Pages Experience and Strength as Antecedents to Engagement and Intensity of Use to Achieve HEIS ' Brand Loyalty"; Clark, Fine, and Scheuer, "Relationship Quality in Higher Education Marketing: The Role of Social Media Engagement"; Jan and Ammari, "Advertising Online by Educational Institutions and Students â€TM Reaction : A Study of Malaysian Universities Advertising Online by Educational Institutions and Students ' Reaction : A Study of Malaysian Universities"; Royo-vela and Hünermund, "Effects of Inbound Marketing Communications on HEIs ' Brand Equity: The Mediating Role of the Student ' S DecisionMaking Process . An Exploratory Research"; Robinson and Celuch, "Strategic and Bonding Effects of Enhancing the Student Feedback Process."

${ }^{18}$ Lee and Merle, "Media Relations and Universities : An Assessment of Digital Newsrooms"; Clark, Fine, and Scheuer, "Relationship Quality in Higher Education Marketing: The Role of Social Media Engagement." 
dimanfaatkan oleh Madrasah Aliyah Matholiul Huda dengan mengunggah video tentang profil, kegiatan kemahasiswaan, kegiatan lembaga dan events penting lainnya.

f. Brosur

Meskipun era digital memberikan kemudahan dalam promosi madrasah namun bukan berarti media konvensional ditinggalkan. Madrasah Aliyah Matholiul Huda Jepara tetap menggunakan brosur dalam promosi madrasah. Hal ini disebabkan sebagian masyarakat masih belum tersentuh oleh teknologi digital. Sebagian masyarakat di desa masih memanfaatkan brosur untuk mengakses informasi melalui brosur / pamphlet ${ }^{20}$. Bagi sebagian masyarakat brosur masih menjadi media pemberi informasi.

${ }^{19}$ Carl Jon et al., "“ Hottest Brand, Coolest Pedagogy ': Approaches to Corporate Branding in Singapore â€TM S Higher Education Sector Branding in Singapore 'S Higher Education Sector" 1241, no. April (2016), doi:10.1080/08841241.2016.1146388; Idris and Whitfield, "Swayed by the Logo and Name: Does University Branding Work?"; Peruta and Shields, "Marketing Your University on Social Media : A Content Analysis of Facebook Post Types and Formats"; Pii-tuulia Nikula and Jussi Kivistö, "Monitoring of Education Agents Engaged in International Student Recruitment: Perspectives From the Agency Theory," 2019, doi:10.1177/1028315318825338; Udo Rainer Gottlieb, Amanda Beatson, and Amanda Beatson, "High on Emotion! Perceived Value: Influencing Decision-Making Processes at International Student Recruitment Trade Shows," Journal of Marketing for Higher Education 0, no. 0 (2018): 1-16, doi:10.1080/08841241.2018.1476430; Rutter, Lettice, and Nadeau, "Brand Personality in Higher Education: Anthropomorphized University Marketing Communications"; Condie et al., "Personalizing Twitter Communication: An Evaluation of "Rotation-Curation' for Enhancing Social Media Engagement within Higher Education."

20 Ai-hsuan Sandra Ma, "The Development of International Student Recruitment Policies in Taiwan: A 60-Year Trajectory," 2014, doi:10.1177/1028315312473781; Andrea M Pampaloni, Journal of Marketing for Higher Education The Influence of Organizational Image on College Selection: What Students Seek in Institutions of Higher Education, 2010, doi:10.1080/08841241003788037; Gai, Xu, and Pelton, "A Netnographic Analysis of Prospective International Students , Decision-Making Process: Implications for Institutional Branding of American Universities in the Emerging Markets"; Agnihotri et al., "Developing a Stakeholder Approach for Recruiting Top-Level Sales Students"; Herold, Tarkiainen, and Sundqvist, "How the Source of Word-of-Mouth Influences Information Processing in the Formation of Brand Attitudes." 


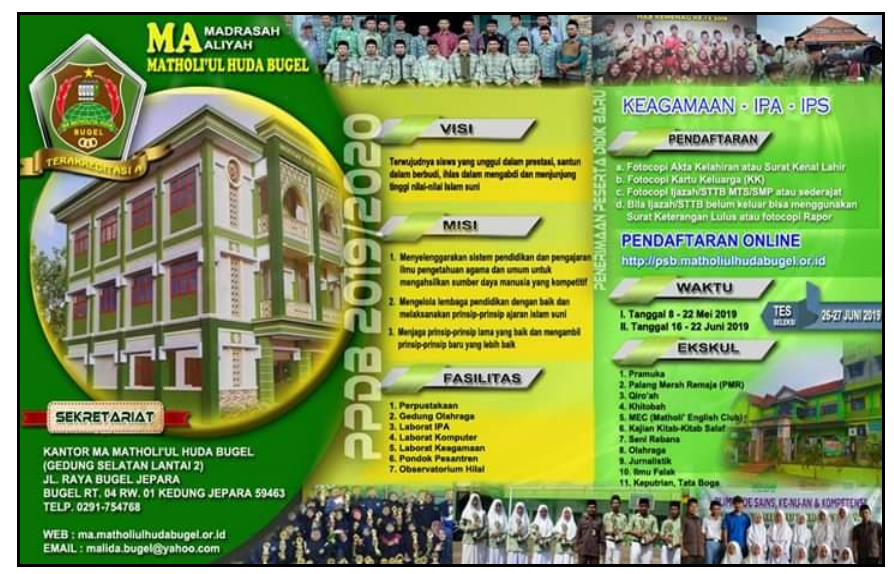

Figure 4. brochure of Madrasah Aliyah Matholiul Huda Jepara

g. Pameran pendidikan

Education fairs atau pameran pendidikan banyak dilakukan juga oleh banyak lembaga pendidikan untuk media promosi 21. Madrasah Aliyah Matholiul Huda Jepara memanfaatkan Pameran pendidikan sebagai media promosi. Hal ini penting dilakukan karena madrasah dapat berinteraksi langsung dengan masyarakat untuk memasarkan Madrasah. Education fairs biasanya diikuti oleh banyak madrasah bahkan universitas. Kegiatan ini umumnya dilakukan di Gedung Wanita RA Kartini Jepara. Kegiatan ini merupakan kegiatan rutin yang dilakukan setahun sekali.

h. Kharisma tokoh pendiri (founding fathers)

Figur pendiri Yayasan yang menaungi Madrasah Aliyah Matholiul Huda Jepara seperti KH Ali Ahmadi dan KH Mawardi merupakan tokoh kharismatik, fenomenal, dan berpengaruh di Jepara. Namanya dikenal luas sebagai seorang ulama yang populer. Nama besarnya menjadi salah satu magnet bagi masyarakat. Secara tidak langsung hal ini juga menjadi media promosi bagi madrasah. Meskipun kedua tokoh tersebut sudah tiada namun namnya masih dikenang secara turun temurun oleh masyarakat. Perjuangan keduanya dilanjutkan oleh keturunan mereka hingga sekarang.

i. Kharisma dan Leadership pemimpin

Figur tokoh yang menjadi pemimpin lembaga pendidikan Matholiul Huda memberi kontribusi juga dalam promosi madrasah. KH Ahmad Mawardi,

21 Peruta and Shields, "Marketing Your University on Social Media: A Content Analysis of Facebook Post Types and Formats." 
putera KH Mawardi. KH Ahmad Mawardi merupakan seorang guru mursyid yang menjadi pembimbing bagi masyarakat yang jamiyah thoriqoh. Nama besarnya tidak lepas dari nama besar ayahnya. Sehingga sosok KH Ahmad Mawardi juga populer sebagimana nama ayahnya. Hal ini menjadi magnet bagi masyarakat sehingga animo masyarakat terhadap Madrasah Aliyah Matholiul Huda Jepara tetap tinggi.

j. Jaringan ikatan alumni

Ikatan alumni merupakan nilai tambah yang menyumbang pada rekrutmen peserta didik. Melalui ikatan alumni promosi madrasah menjadi semakin luas ruang geraknya. Alumni yang tersebar di dalam maupun luar kota menjadi duta madrasah yang secara langsung maupun tidak langsung memberi kontrinusi terhadap promosi madrasah. Hal ini dapat dilihat dari kegiatan yang diselenggarakan setiap tahun yakni reuni akbar. Kegiatan ini dibagi menjadi dua event dalam setahun. Hal ini dilakukan karena sangat banyaknya alumni dari awal berdirinya tahun 1978 hingga 2019. Sehingga perlu dibatasi berdasrkan angkatan yakni angkatan 1978 smapai 2001 dan angkatan 2002-hingga 2019. Ikatan alumni ini menjadi gerakan besar yang terus bertambah dari tahun ke tahun.

\section{Pembahasan}

Di era cyber 4.0 banyak lembaga pendidikan menggunakan internet dan media sosial sebagai media promosi dan berimplikasi terhadap keterlibatan public terhadap lembaga pendidikan terkait.

Muhammad Tahir Jan dan Djihane Ammari mengungkapkan bahwa media sosial dan situs web secara positif memengaruhi pengambilan keputusan siswa, yang kemudian secara signifikan memengaruhi pilihan siswa terhadap universitas tertentu Social memiliki implikasi yang sangat berharga bagi pembuat kebijakan, terutama di industri pendidikan Malaysia. ${ }^{22}$

Melissa Clark Monica B. Fine and Cara-Lynn Scheuer Hasil Studinya menunjukkan hubungan positif antara siswa mengikuti universitas melalui media sosial dan persepsi memiliki hubungan berkualitas tinggi dengan universitas

${ }^{22}$ Jan and Ammari, "Advertising Online by Educational Institutions and Students â $€^{\mathrm{TM}}$ Reaction : A Study of Malaysian Universities Advertising Online by Educational Institutions and Students ' Reaction : A Study of Malaysian Universities." 
mereka, dan bahwa mengikuti universitas di beberapa situs media sosial mengarah ke persepsi kualitas hubungan yang lebih tinggi. Hasilnya memberikan implikasi penting dan tepat waktu untuk universitas dan pemasar pendidikan tinggi. Temuannya menunjukkan bahwa pemasar pendidikan tinggi harus menginvestasikan sumber daya dalam komunikasi media sosial untuk membentuk hubungan berkualitas tinggi dengan para pemangku kepentingan mereka. Melissa Clark, Monica B. Fine \& Cara-Lynn Scheuer menawarkan platform sosial media tidak menjamin siswa akan mengakses atau terlibat dengan situs-situs tersebut. Hal yang lebih penting bagi lembaga pendidikan adalah mengembangkan stategi untuk mendorong penggunaan media sosial. Misalnya, lembaga mungkin ingin mempertimbangkan untuk mengadakan kontes reguler di situs media sosial mereka atau memanfaatkan fitur 'polling' yang tersedia di platform media sosial tertentu untuk meningkatkan keterlibatan siswa dan / atau untuk mendorong partisipasi dalam situs-situs tertentu. ${ }^{23}$

Yimei Zhu menyatakan bahwa komunikasi lintas budaya dan pemasaran media sosial. Ini adalah studi pertama dari skala ini yang meneliti penggunaan institusi-institusi pendidikan tinggi barat dari media sosial Tiongkok dan hubungannya dengan rekrutmen siswa dari siswa pendidikan tinggi internasional China. Sejak 2012 samapai dengan 2018 mengungkapkan peningkatan siswa China di lembaga pendidikan tinggi UK. Hal ini nampak dari peningkatan jumlah pengikut di akun Weibo universitas, setelah memperhitungkan reputasi universitas. $^{24}$

Felicitas M. Brech dkk menyatakan bahwa pelibatan penggemar dan komunitas di media sosial melalui interaksi dengan institusi pendidikan tinggi di Facebook. reputasi memiliki dampak yang lebih kuat pada ukuran penggemar daripada ukuran universitas. Lebih kanjut menyatakan bahwa semakin lama

\footnotetext{
${ }^{23}$ Clark, Fine, and Scheuer, "Relationship Quality in Higher Education Marketing: The Role of Social Media Engagement."

${ }^{24}$ Yimei Zhu, "Social Media Engagement and Chinese International Student Recruitment: Understanding How UK HEIs Use Weibo and WeChat," Journal of Marketing for Higher Education 29, no. 2 (2019): 1-18, doi:10.1080/08841241.2019.1633003.
} 
sebuah universitas terlibat dengan Facebook, semakin banyak penggemar yang tertarik. $^{25}$

Liz C. Wang, John (Jack) Gault, Paul Christ and Patricia A. Diggin Sekolah dapat memberikan informasi yang ditujukan kepada influencer penting ini, seperti melalui pemasaran media sosial, dengan tujuan agar influencer ini mendorong sarjana untuk berpartisipasi dalam program studi di luar negeri atau student abriad program (SAP). Hasil ini menunjukkan bahwa universitas dapat meningkatkan partisipasi siswa ${ }^{26}$

Meskipun banyak studi menyatakan internet dan media sosial berdampak positif terhadap keterlibatan public namun media sosial bukan jaminan. Namun ada faktor-faktor lain yang juga menentukan keberhasilan promosi sekolah seperti studi Adam Perutaa and Alison B. Shields Hasil menunjukkan bahwa ada perbedaan signifikan dalam keterlibatan yang diterima pada posting di seluruh jenis lembaga. Selain itu, jenis media dan frekuensi pengiriman adalah faktor yang berkontribusi terhadap keterlibatan. Studi ini memberikan arahan tentang bagaimana manajer media sosial universitas dapat mengelola konten media sosial mereka dengan lebih baik untuk meningkatkan keterlibatan dan meningkatkan jangkauan posting mereka. Lebih lannjut ia menyatakan dari 66 perguruan tinggi dan universitas top AS dan keterlibatan dari konstituen mereka pada posting Facebook. Namun keberhasilan rekrutmen melalui media sosial dipengaruhi oleh jenis media, dan frekuensi pengiriman konten yang diminati oleh publik. ${ }^{27}$

Demikian juga studi James Pringle \& Samantha Fritz media sosial dimanfaatkan untuk branding dengan menampilkan konten yang berisi janji-janji yang ditawarkan kepada publik. Tujuannya adalah menambahkan dukungan pada konseptualisasi bahwa keaslian dibentuk oleh persepsi pribadi konsumen tentang apa yang asli dan dengan tujuan untuk memperkuat autentisitas yang dirasakan

\footnotetext{
${ }^{25}$ Felicitas M Brech et al., "Engaging Fans and the Community in Social Media : Interaction with Institutions of Higher Education on Facebook," Journal of Marketing for Higher Education 27, no. 1 (2016): 1-19, doi:10.1080/08841241.2016.1219803.

${ }^{26}$ Liz C Wang et al., "Individual Attitudes and Social Influences on College Students ' Intent to Participate in Study Abroad Programs," JOM FISIP 26, no. 1 (2016): 103-28, doi:10.1080/08841241.2016.1146385.

${ }^{27}$ Peruta and Shields, "Marketing Your University on Social Media: A Content Analysis of Facebook Post Types and Formats."
} 
melalui pengartian bersama. Meskipun setelah diteliti meskipun sebagian besar dapat dipercaya namun ada nuansa abu-abu. ${ }^{28}$

\section{Penutup}

Berdasarkan pembahasan tersebut di atas bahwasannya keberhasilan Madrasah tidak lepas dari strategi promosi yang telah dilakukan. Staregi yang ditempuh oleh Madrasah Aliyah Matholiul Huda Jepara tergolong khas. Promosi madrasah yang dilakukan dalam rangka merekrut siswa tergolong unik jika dibandingkan dengan lembaga pengelola pendidikan pada umumnya. Untuk memenangkan persaingan dalam bursa rekrutmen siswa dan merebut hati masyarakat, Madrasah Aliyah Matholiul Huda Jepara menempuh strategi yang merupakan kombinasi antara metode dan media.

Metode yang digunakan dapat diketegorikan kedalam dua kategori. Pertama, promosi langsung. Metode ini dilakukan dengan melakukan interaksi secara langsung kepada masyarakat dengan mempublikasikan profil madrasah yang meliputi prestasi, keunggulan madrasah, fasilitas dan lainnya. Kedua, promosi tidak langsung. Metode tidak langsung ini adalah suatu yang berbeda dibandingkan dengan lembaga penyelenggara pendidikan lainnya terutama di era 4.0. Metode tidak langsung ini adalah stigma positif yang melekat dan mengakar di masyarakat tentang lembaga dan sosok kharismatik tokoh pendiri madrasah. Sosok kharismatik tersebut adalah Kiai Mawardi dan Ali Ahmadi. Citra positif yang kedua adalah Madrasah Aliyah Matholiul Huda Jepara merupakan pionir yang melahirkan tokoh-tokoh dan ulama besar di Jepara yang berkiprah di masyarakat.

Media yang digunakan oleh Madrasah Aliyah Matholiul Huda Jepara meliputi dua jenis media. Pertama, media online dengan memanfaatkan internet dan media sosial. Promosi madrasah dilakukan melalui web madrasah, facebook, twitter, instagram, youtube yang menampilkan profil madrasah yang meliputi prestasi, keunggulan madrasah, fasilitas dan events lainnya. Kedua, media off line (charisma dan leadership dan jaringan ikatan alumni)

${ }^{28}$ James Pringle and Samantha Fritz, "The University Brand and Social Media: Using Data Analytics to Assess Brand Authenticity," Journal of Marketing for Higher Education 29, no. 1 (2018): 1-26, doi:10.1080/08841241.2018.1486345. 


\section{Daftar Pustaka}

Agnihotri, Raj, Leff Bonney, Andrea Leigh Dixon, Ellen Bolman Pullins, and Jane Z Sojka. 2014 ."Developing a Stakeholder Approach for Recruiting Top-Level Sales Students,”. doi:10.1177/0273475314522039.

Baker, Michael J. 1991. RESEARCH FOR MARKETING. 1st ed. London: MACMILLAN EDUCATION LTD.

Brech, Felicitas M, Uwe Messer, Brian A Vander Schee, A Philipp, and Bjoern S Ivens. 2016. "Engaging Fans and the Community in Social Media: Interaction with Institutions of Higher Education on Facebook." Journal of Marketing for Higher Education 27, no. 1 : 1-19. doi:10.1080/08841241.2016.1219803.

Clark, Melissa, Monica B Fine, and Cara-lynn Scheuer. 2017. "Relationship Quality in Higher Education Marketing: The Role of Social Media Engagement." Journal of Marketing for Higher Education 27, no. 1 : 40-58. doi:10.1080/08841241.2016.1269036.

Condie, Jenna Marie, Ivett Ayodele, Sabirah Chowdhury, Shelley Powe, Jenna Marie, Ivett Ayodele, Sabirah Chowdhury, and Shelley Powe. 2018. "Personalizing Twitter Communication: An Evaluation of " RotationCuration' for Enhancing Social Media Engagement within Higher Education." Journal of Marketing for Higher Education 28, no. 2 (): 1-18. doi:10.1080/08841241.2018.1453910.

Davari, Mehraneh, Payam Noursalehi, and Abbas Keramati. 2018 "Data Mining Approach to Professional Education Market Segmentation : A Case Study." Journal of Marketing for Higher Education 29, no. 1 : 1-22. doi:10.1080/08841241.2018.1545724.

Education, Directorate of Distance. 2012. Research Methodology. New Delhi: EXCEL BOOKS PRIVATE LIMITED,.

Gai, Lili, Chunhao Xu, and Lou E Pelton. 2016. “A Netnographic Analysis of Prospective International Students ' Decision-Making Process : Implications for Institutional Branding of American Universities in the Emerging Markets." Journal of Marketing for Higher Education 26, no. 2 : 1-18. doi:10.1080/08841241.2016.1245233. 
Gottlieb, Udo Rainer, Amanda Beatson, and Amanda Beatson. 2018. "High on Emotion! Perceived Value: Influencing Decision-Making Processes at International Student Recruitment Trade Shows.” Journal of Marketing for Higher Education 0, no. 0 : 1-16. doi:10.1080/08841241.2018.1476430.

Hardaker, Glen, and Aishah Ahmad Sabki. 2019. Pedagogy in Islamic Education: The Madrasah Context. 1st ed. United Kingdom: Emerald Group Publishing. Herold, Kristiina, Anssi Tarkiainen, and Sanna Sundqvist. 2016. "How the Source of Word-of-Mouth Influences Information Processing in the Formation of Brand Attitudes" 1241 . doi:10.1080/08841241.2016.1146387.

Idris, Muhammad Zaffwan, and T W Allan Whitfield. 2015 ."Swayed by the Logo and Name: Does University Branding Work?" Journal of Marketing for Higher Education 24, no. 1 : 37-41. doi:10.1080/08841241.2014.919979.

Ii, Reginald T Dillingham, William S Breffle, Matthew C Kelly, Reginald T Dillingham, William S Breffle, and Matthew C Kelly. 2018. "A Latent-Class Discrete-Choice Model of Demand for Economics Electives : A Case Study on the Challenge to Increase Enrollment" 1241 . doi:10.1080/08841241.2018.1426673.

Jan, Muhammad Tahir, and Djihane Ammari. 2016. “Advertising Online by Educational Institutions and Students $€^{\mathrm{TM}}$ Reaction : A Study of Malaysian Universities Advertising Online by Educational Institutions and Students ' Reaction: A Study of Malaysian Universities." Journal of Marketing for Higher Education 26, no. 2 : 1-13. doi:10.1080/08841241.2016.1245232.

Jon, Carl, Way Ng, Carl Jon, and Way Ng. 2016. “" Hottest Brand , Coolest Pedagogy ': Approaches to Corporate Branding in Singapore $\hat{a} €^{\mathrm{TM}} \mathrm{S}$ Higher Education Sector Branding in Singapore' S Higher Education Sector" 1241, no. April. doi:10.1080/08841241.2016.1146388.

Kittle, Bart, Diane Ciba, Bart Kittle, and Diane Ciba. 2008. "Journal of Marketing for Higher Education Using College Web Sites for Student Recruitment: A Relationship Marketing Study Using College Web Sites for Student Recruitment : A Relationship Marketing Study," no. October 2014 : 37-41. doi:10.1300/J050v11n03.

Kothari, C. R. 2004. Research Methodology: Methods \& Techniques. New Delhi, 
India: New Age International (P) Limited, Publisher.

Kumar, Ranjit. 2011. RESEARCH METHODOLOGY. 3rd ed. Los Angeles, London, New Delhi, Singapore, Washington DC: SAGE Publications Ltd.

Laouamer, Lamri, and Omar Tayan. 2013. “An Enhanced SVD Technique for Authentication and Protection of Text-Images Using a Case Study on Digital Quran Content with Sensitivity Constraints." Life Science Journal 10, no. 2 : 2591-97.

Lee, Nicole M, and Patrick F Merle. 2018. "Media Relations and Universities : An Assessment of Digital Newsrooms." Journal of Marketing for Higher Education 28, no. 2 : 1-15. doi:10.1080/08841241.2018.1467991.

Ma, Ai-hsuan Sandra. 2014. "The Development of International Student Recruitment Policies in Taiwan: A 60-Year Trajectory,”. doi:10.1177/1028315312473781.

Muhaimin, Sutiah, and Sugeng Listyo Prabowo. 2015. Manajemen Pendidikan: Aplikasinya Dan Penyusunan Rencana Pengembangan Sekolah Dan Madrasah. 5th ed. Jakarta: Prenada Media Gorup,.

Neuman, W Lawrence. 2014. Social Research Methods: Qualitative and Quantitative Approaches. 7th ed. United States of America: Pearson Education Limited,.

Nikula, Pii-tuulia, and Jussi Kivistö. 2019. "Monitoring of Education Agents Engaged in International Student Recruitment: Perspectives From the Agency Theory,”. doi:10.1177/1028315318825338.

"No Title," 1992.

Pampaloni, Andrea M. 2010. Journal of Marketing for Higher Education The Influence of Organizational Image on College Selection : What Students Seek in Institutions of Higher Education,. doi:10.1080/08841241003788037.

Pandey, Prabhat, and Meenu Mishra Pandey. 2015. RESEARCH METHODOLOGY: TOOLS AND TECHNIQUES. Romania, European Union: BRIDGE CENTER.

Peruta, Adam, and Alison B Shields. 2018 ."Marketing Your University on Social Media : A Content Analysis of Facebook Post Types and Formats." Journal of Marketing for Higher Education 28, no. 2: 1-17. 
doi:10.1080/08841241.2018.1442896.

Pringle, James, and Samantha Fritz. "The University Brand and Social Media: Using Data Analytics to Assess Brand Authenticity.” 2018. Journal of Marketing for Higher Education 29, no. 1: 1-26. doi:10.1080/08841241.2018.1486345.

Pusey, André. 2016. "Strike, Occupy, Transform! Students, Subjectivity and Struggle” 1241, no. November . doi:10.1080/08841241.2016.1240133.

Religion Ministry of Jepara Regency. 2018. “Open Data Kabupaten Jepara,". http://opendata.jepara.go.id/id/group/pendidikan website:

http://opendata.jepara.go.id/id/dataset/jumlah-madrasah-ibtidaiyah-swastakabupaten-jepara-tahun-2018.

"Research Methods," n.d.

Research Methods in Psychology PSYCHOLOGICAL RESEARCH OBJECTIVES AND GOALS , PROBLEMS , HYPOTHESIS AND, n.d.

Robinson, Nadine M, and Kevin G Celuch. 2016. "Strategic and Bonding Effects of Enhancing the Student Feedback Process" 26, no. 1 : 20-40. doi:10.1080/08841241.2016.1146386.

Robson, Julie, Jillian Dawes Farquhar, Christopher Hindle, and Julie Robson. 2017. "Working up a Debt: Students as Vulnerable Consumers Working up a Debt: Students as Vulnerable Consumers." Journal of Marketing for Higher Education 0, no. 0 (): 1-16. doi:10.1080/08841241.2017.1391922.

Royo-vela, Marcelo, and Ute Hünermund. 2016. "Effects of Inbound Marketing Communications on HEIs 'Brand Equity: The Mediating Role of the Student' S Decision-Making Process . An Exploratory Research.” Journal of Marketing for Higher Education 26, no. 2: 1-25. doi:10.1080/08841241.2016.1233165.

Rutter, Richard, Fiona Lettice, and John Nadeau. 2016. "Brand Personality in Higher Education: Anthropomorphized University Marketing Communications" 1241, no. August (). doi:10.1080/08841241.2016.1213346.

Salgado, Esperanza Garza, and Marcelo Royo Vela. 2019. "Brand Fan Pages Experience and Strength as Antecedents to Engagement and Intensity of Use 
to Achieve HEIS ' Brand Loyalty." Journal of Marketing for Higher Education 29, no. 1 : 102-20. doi:10.1080/08841241.2019.1605437.

Scullion, Richard, and Mike Molesworth. 2016. "Normalisation of and Resistance to Consumer Behaviour in Higher Education" 1241, no. November . doi:10.1080/08841241.2016.1248104.

Shah, Kruti. 2009. Advertising And Promotion An IMC Perspective. New Delhi: Tata McGraw-Hill Education,.

Walliman, Nicholas. 2011. RESEARCH METHODS THE BASICS. USA and Canada: Routledge.

Wang, Liz C, John Jack Gault, Paul Christ, Patricia A Diggin, Liz C Wang, John Jack Gault, Paul Christ, and Patricia A Diggin. "Individual Attitudes and Social Influences on College Students ' Intent to Participate in Study Abroad Programs." JOM FISIP 26, no. 1 2016: 103-28. doi:10.1080/08841241.2016.1146385.

Young, Mark R, and Mark R Young. "Journal of," no. May 20092010. doi:10.1177/0273475309335353.

Zhu, Yimei. "Social Media Engagement and Chinese International Student Recruitment: Understanding How UK HEIs Use Weibo and WeChat." Journal of Marketing for Higher Education 29, no. 2 2019: 1-18. doi:10.1080/08841241.2019.1633003. 